\title{
The Effect of Elevation on the Sucrose Content of Sugarcane
}

\author{
M. A. Lugo-López and B. G. Capón
}

INTRODUCTION

In Puerto Rico sugarcane is grown under a wide range of climatic conditions, rainfall being the main variable, in a large number of soil types with many extreme soil conditions, and at various altitudes ranging from almost sea level to over 1,500 feet. A large number of varieties are grown and there are differences in fertilization and other cultural practices. The variability in sucrose yields is rather large with many extremely low levels. Studies are under way with the objective of determining the fundamental reasons underlying those variations. In previous and forthcoming papers $(2,3,6)^{2}$ the influences of weather and climate, varieties, and fertilizer upon sucrose yields at harvesttime have been and will be reported and discussed.

It has been observed by many agriculturists that sugarcane grown at higher elevations yields juices richer in sucrose than when grown at lower altitudes. However, very little information is to be found in the available literature. Quintus (4) reported: "Besides rainfall, elevation above sea level affects the formation of saccharose. On estates situated at a high elevation, less cane is always produced, which disadvantage is partly or wholly made up by a greater sugar percent". In 1919, a report from Hawaii (5) recognized that, although there were differences in the behavior of cane varieties grown at different elevations, most varieties produced maximum sucrose at elevations of around 1,500 feet. The influence of elevation upon the sugarcane plant is, in all probability, closely related to climatic influences, particularly temperature. Geerligs (1) reported: "On plantations situated considerably above sea level the low night temperatures stop the growth and promote ripening".

This paper presents data to show the effect of elevation upon the sucrose content of sugarcane grown in Puerto Rico.

\section{MATERIALS AND METHODS}

Data covering the period 1939-49 were gathered from a large number of commercial fields of east-central Puerto Rico. Elevations were obtained for each field by superimposing topographic maps over field-distribution maps. They were subsequently spot-checked with a Short and Mason aneroid barometer. The data were classified and grouped by varieties and altitude

${ }^{1}$ Associate Soil Scientist and Associate Director for Research, respectively, Agricultural Experiment Station, University of Puerto Rico, Río Piedras, P. R.

${ }^{2}$ Numbers in parentheses refer to Literature Cited, p. 131. 
intervals, disregarding climatic and edaphic differences. However, rainfall differences were not marked over most of the area studied and the differences in mean temperature were slight. Variations in soil types were numerous. Four sugarcane varieties were included in the study, namely, P.O.J. 2878, B.H. 10(12), P.R. 803, and F.C. 916. The study includes data from 695 crops harvested during the 10 -year investigation period at the various altitude intervals in an attempt to explain at least some of the variability observed.

\section{RESULTS AND DISCUSSION}

Table 1 summarizes the study of the relation between sucrose content at harvesttime and field elevation. The over-all picture indicates that sugarcane grown at lower elevations tends to contain less sucrose than that grown at higher elevations. In general, the main differences occur in canes grown 1 to $10 \mathrm{~m}$. above mean sea level and canes grown at the highest elevations studied. The differences among the other class intervals are negligible. A differential response among varieties can also be observed in table 1. Some varieties like P.O.J. 2878 and P.R. 803 yielded juices of very low sucrose content when grown at elevations ranging from 1 to $10 \mathrm{~m}$. above mean sea

TABLE 1.-Mean yields of available $96^{\circ}$ sugar-percent-cane of 4 sugarcane varieties when grown at various elevations

\begin{tabular}{c|c|c}
\hline Variety and number of crops & Elevation $(\mathrm{m})$. & Available $96^{\circ}$ sugar yields \\
\hline Variety P.O.J. 2878: & & Percentcane \\
35 & & \\
170 & $1-10$ & 9.48 \\
97 & $10-100$ & 11.52 \\
49 & $100-200$ & 11.61 \\
Variety B.H. 10(12): & $200-400$ & 11.72 \\
170 & $1-10$ & 11.30 \\
47 & $10-100$ & 12.13 \\
24 & $100-200$ & 12.01 \\
P.R. $803:$. & $1-10$ & 9.42 \\
6 & $10-100$ & 11.57 \\
15 & $100-200$ & 12.04 \\
23 & $1-10$ & 10.63 \\
Variety & $10-100$ & 11.56 \\
7 & $1-10$ & 10.94 \\
6 & $10-100$ & 11.62 \\
Variety $916:$ & $100-200$ & 11.79 \\
242 & $200-400$ & 11.78 \\
259 & & \\
144 & & \\
50 & &
\end{tabular}


TABLE 2.-Monthly fluctuations in maximum, minimum, and mean temperature $\left({ }^{\circ} \mathrm{F}.\right)$ at 2 selected stations located at different elevations

\begin{tabular}{|c|c|c|c|c|c|c|}
\hline \multirow{3}{*}{ Months } & \multicolumn{5}{|c|}{ Temperature at indicated locations } & \multirow{2}{*}{ n) } \\
\hline & \multicolumn{3}{|c|}{ Humacao (low elevation) } & \multicolumn{2}{|c|}{ Cayey (high elevation) } & \\
\hline & Maximum & Minimum & Mean & Maximum & Minimum & Mean \\
\hline January... & 83.2 & 59.8 & 72.3 & 85.0 & 51.0 & 68.4 \\
\hline February... & 84.7 & 58.3 & 72.4 & 85.2 & 50.0 & 68.2 \\
\hline March....... & 87.0 & 59.0 & 74.3 & 86.8 & 50.7 & 70.6 \\
\hline April....... . & 87.8 & 61.3 & 76.1 & 88.2 & 53.4 & 72.0 \\
\hline May.......... & 88.5 & 66.3 & 78.7 & 90.5 & 56.5 & 74.2 \\
\hline June......... & 88.8 & 69.7 & 79.9 & 88.8 & 61.8 & 75.6 \\
\hline July . . . . . . . & 89.7 & 69.5 & 79.8 & 89.4 & 62.5 & 75.5 \\
\hline August ...... & 91.5 & 70.2 & 80.2 & 90.4 & 60.6 & 75.3 \\
\hline September.... & 90.6 & 69.2 & 78.9 & $88: 8$ & 60.3 & 75.2 \\
\hline October..... & 90.0 & 68.2 & 78,4 & 88.8 & 60.0 & 75.0 \\
\hline November........... & 87.2 & 64.2 & 75.9 & 88.2 & 59.7 & 73.4 \\
\hline December....... & 84.0 & 60.8 & 73.6 & 87.0 & 54.8 & 70.9 \\
\hline
\end{tabular}

level. Others produced juices of better quality. The differences in sucrose yields among the leading varieties commercially grown in Puerto Rico have already been discussed (3).

Table 2 gives the monthly temperatures at two selected stations representative of low and high sugarcane-producing areas: Humacao, on the east coast, and Cayey in the east-central mountains. In general, there is a difference in mean temperatures of about $4^{\circ} \mathrm{F}$. between the two stations. Differences in maximum temperatures are negligible, but differences in minimum temperatures are of the order of $8^{\circ} \mathrm{F}$. on the monthly basis. Thus the sugarcane planted at high altitudes enjoys about the same benefits from sunlight, as measured by "total day-degrees", with the added advantage of much cooler nights than the sugarcane planted on low sites. Hence, the beneficial effect of relatively high altitudes upon sucrose yields may reflect the influence of cool nights. There is also the possibility of some parallelism between the effects of elevation and soil conditions.

\section{SUMMARY}

Data are presented to show the influence of elevation on sucrose yields of four varieties of sugarcane: P.O.J. 2878, B.H. 10(12), P.R. 803, and F.C. 916. An over-all examination of the data from 695 crops harvested during a 10-year period, 1939-49, disclosed that elevations higher than $10 \mathrm{~m}$. above mean sea level favor high sucrose accumulation in sugarcane. This effect

${ }^{3}$ Degrees above $70^{\circ} \mathrm{F}$. for a given period. 
was more pronounced with some varieties than with others. This influence of altitude is probably a reflection of climatic effects. Data are presented to show that cane growing at high elevations within a given area, enjoys about the same benefits from sunlight, as measured by "total day-degrees", with the added advantage of cooler nights.

\section{RESUIMEN}

En este trabajo se presentan datos que demuestran cómo influye la altitud a que se siembra la caña de azúcar sobre sus rendimientos de sacarosa. Cuando se hace un estudio de estos datos se percibe el hecho de que la caña que se siembra a más de $10 \mathrm{~m}$. sobre el nivel del mar produce jugos más ricos en sacarosa que la de sitios más bajos. Este efecto de la altura sobre el mayor o menor contenido de sacarosa en la caña es con toda probabilidad una acción refleja de los efectos del clima.

Específicamente se aportan datos que señalan que la caña de azúcar en sitios altos, además de recibir los efectos beneficiosos de la radiación solar de igual manera que la que crece a menor altitud, también recibe los efectos de una temperatura más baja durante la noche.

\section{LITERATURE CITED}

1. Geerligs, H. C., Cane sugar and its manufacture, 1924; cited by Das, U. K.; Hawaiian Planters' Rec. 35 163-201 1931.

2. Lugo-López, M. A. and Capó, B. G., The effect of weather and climate on the sucrose content of sugarcane, J. Agr. Univ. P.R. 38 (4) 1954.

3. Lugo-López, M. A., Samuels, G., and Méndez, F., Factors affecting the sucrose content of sugarcane: III, Varieties, J. Agr. Univ. P.R. 37 (1) 28-34 1953.

4. Quintus, R. A., The cultivation of sugareane in Java, 1923; eited by Das, U. K.; Hawaiian Planters' Rec. 35 163-201, 1931.

5. Report of the committee in charge of the Experiment Station of the Hawaiian Sugar Producers' Association, p. 29, 1919.

6. Samuels, G., Lugo-López, M. A., and Landrau Jr., P., Factors affecting the sucrose content of sugarcane: Fertilizers, J. Agr. Univ. P.R. 36 (3) 194-202, 1952. 